\title{
CXCL10 wt Allele
}

National Cancer Institute

\section{Source}

National Cancer Institute. CXCL10 wt Allele. NCI Thesaurus. Code C49756.

Human CXCL10 wild-type allele is located within 4 q21 and is approximately $2 \mathrm{~kb}$ in length. This allele, which encodes $\mathrm{C}-\mathrm{X}-\mathrm{C}$ motif chemokine 10 protein, plays a role in both immune cell migration and in the modulation of adhesion molecule expression. 